\title{
STUDY ON IMMOBILIZED CHLORELLA SP. BY NANO MUSSEL- SHELL POWDER AND CHITOSAN
}

\author{
WEI, D. Y. ${ }^{1}-$ CAI, L. ${ }^{2}-$ JIANG, D. J. ${ }^{3}-$ GUO, J. ${ }^{4}-$ WANG, Y. N. ${ }^{5}-$ JI, L. L. ${ }^{5 *}-$ SONG, W. D. ${ }^{6 *}$ \\ ${ }^{I}$ College of Naval Architecture and Mechanical-electrical Engineering, Zhejiang Ocean University \\ Haida South Road No.1, Lincheng Street, Dinghai District, 316022 Zhoushan, China \\ (phone: +86-580-226-2589; fax: +86-580-226-2063) \\ ${ }^{2}$ College of Environmental and Science Technology, Donghua University \\ 201620 Shanghai, China \\ ${ }^{3}$ College of Marine Science and Technology, Zhejiang Ocean University \\ 316022 Zhoushan, China \\ ${ }^{4}$ College of Food and Medical, Zhejiang Ocean University, 316022 Zhoushan, China \\ ${ }^{5}$ Institute of Innovation \& Application, Zhejiang Ocean University, 316022 Zhoushan, China \\ ${ }^{6}$ College of Petrochemical and Energy Engineering, Zhejiang Ocean University \\ 316022 Zhoushan, China \\ *Corresponding authors \\ L.Ji-e-mail: jll-gb@163.com; W.Song-e-mail:swd60@163.com \\ phone: +86-580-226-2589; fax: +86-580-226-2063 \\ (Received 25 $5^{\text {th }}$ May 2018; accepted $17^{\text {th }}$ Jul 2018)
}

\begin{abstract}
Shells were used to produce biomass materials through calcining due to their excellent mechanical properties. In this paper, the mussel shells were calcined by the vacuum tube furnace and muffle furnace at $600{ }^{\circ} \mathrm{C}, 700{ }^{\circ} \mathrm{C}$ and $800{ }^{\circ} \mathrm{C}$ respectively, and that prepared under optimum conditions was activated by $\mathrm{K}_{2} \mathrm{CO}_{3}$ in the hydrothermal method. The pore structure and morphology of the sample were characterized by specific surface area analyser (BET) and scanning electron microscopy (SEM). Then the Chlorella sp. was immobilized by mussel shell powder and chitosan, which was co-cultured for 60 days. The results showed that calcined shells at $700{ }^{\circ} \mathrm{C}$ in a vacuum tube furnace have an optimal specific surface area, up to $4.107 \mathrm{~m}^{2} / \mathrm{g} . \mathrm{K}_{2} \mathrm{CO}_{3}$ hydrothermal modification method could effectively enlarge the pores of shell powder, from $4.107 \mathrm{~nm}$ up to $16.557 \mathrm{~nm}$. The shell powder modified by chitosan had positive charges, which could attract the microalgae with negative charges, could live for up to 60 days. This article aims to use waste shells to immobilize microalgae, which is not only of great importance to the protection of the environment but also provides a novel way to immobilize microalgae.

Keywords: Chlorella sp., immobilization, nanoporous mussel shell materials, microstructural characterization, recovery growth rate
\end{abstract}

\section{Introduction}

Biomass has been assigned numerous roles to human beings from ancient times because of its massive and recyclable nature, however, with the rapid expansion of manmade materials, like alloy, plastic fibre, and so on, a great number of natural materials have been neglected and abandoned. Most of the non-renewable and non-biodegradable synthetic materials were used and subsequently became wastes, resulting in seriously environmental "white pollution" at present (Wang et al., 2017). Therefore, high-value utilization of biomass resources has been paid more and more attention to researchers 
because of their renewability and biodegradability (Wang et al., 2016). Shells are often used to prepare porous materials by calcination as carrier-loaded functional ions due to its main component is $95 \% \mathrm{CaCO}_{3}$ and a small amount of organic matter (Currey et al., 1977; Okumura and Gennes, 2001; Currie et al., 2007). The previous study was performed a shell-based catalyst by the impregnation process using potassium hydroxide to extract economical biodiesel fuel synthesis from castor oil (Nurdin et al., 2015). The current use of seashells is limited to feed additives (J. et al., 2013), adsorbents (Paradelo et al., 2016), cement reinforcing phase (Martinez-Garcia et al., 2016), antimicrobials (Li et al., 2016), and carriers for functional materials (Edralin et al., 2017) at present.

Chlorella sp. is a kind of unicellular green microalgae that around $40 \%$ of global photosynthesis is performed by microalgae (Myers, 1980). From the 1960s, Oswald et al. first found the chlorella in the oxidized pond had an excellent removal effect on nitrogen and phosphorus in the water (Oswald et al., 1957). However, due to its small size of single cells, the presence of free-living microalgae in treated effluents remains a problem (Chevalier and Noüe, 1985), so researchers focused on the use of immobilized microalgae (Jiménez-Pérez et al., 2004). Immobilization techniques can be primarily divided into two groups: "passive" and "active" immobilization (Moreno-Garrido, 2008). Because the microalgae tends to adhere and naturally grow on the surface of natural organisms, the "passive" immobilization mostly uses it as a carrier (Robinson et al., 1986), but this process is easily reversed. Therefore, the "active" immobilization method, such as chemical attachment (Moreira et al., 2006), flocculant agents (Seki and Suzuki, 2002), and gel entrapment (Solé and Matamoros, 2016), are most widely used. Alginate gel, a gel entrapment type, has been most widely used because the immobilized cells do not undergo extreme physicochemical changes during the immobilization process (Smidsrød and Skja ${ }^{\circ} \mathrm{K}-\mathrm{Br} 1 \mathrm{~K}, 1990$ ).

Most frequent current uses of chlorella sp. are the metabolite production cultured, improvement of culture collections handling, obtaining of energy, nutrients, removement of metal or organic pollutant from aquatic media, measurement of toxicity and co-immobilization system production for different purposes (Abdel-Raouf et al., 2012). The use of immobilized algal cells in water purification processes has been reported previously (Bruun, 2013) as microalgae form part of the organisms fixed in percolating filters of wastewater treatment plants. At present, the immobilization technology of microalgae mostly uses natural polymer materials as carriers, such as agar(Kandilian et al., 2017), alginate (Smidsrød and Skja ${ }^{\circ}$ K-BrtK, 1990) and so on. The advantage of these materials is that they have good biocompatibility, but the immobilization power is not strong, as a result, the microalgae is easy to fall off. In addition, the polymeric polymer material as a carrier to immobilized microalgae has the disadvantages of low biocompatibility and toxicity to microalgae cells (Timofeeva and Kleshcheva, 2011). There are few reports on the use of porous biomass materials as carriers to immobilize microalgae.

In this paper, mussel shell was calcined, activated and modified by chitosan, used to be as a carrier, to immobilize microalgae. Because modified shell has positive charges, it could attract the microalgae with negative charges, and achieve microalgae immobilization with a strong immobilization power. At the same time, Chitosan has the dual functions of electric neutral flocculation and adsorption flocculation, which is not only can provide nutrients for the growth of microalgae, but also non-toxic and harmless. This material will has broad prospects in the field of water quality control. 


\section{Materials and methods}

\section{Materials}

Mussel shell was provided by a food processing factory (Zhejiang province, China). Chlorella sorokiniana was obtained from the laboratory of Marine Biological Chemical Laboratory, Zhejiang Ocean University. BG-11 medium $\left(\mathrm{NaNO}_{3}, 1.5 \mathrm{~g}\right.$; $\mathrm{K}_{2} \mathrm{HPO}_{4}, 0.04 \mathrm{~g} ; \mathrm{MgSO}_{4} .7 \mathrm{H}_{2} \mathrm{O}, 0.075 \mathrm{~g} ; \mathrm{CaCl}_{2} .7 \mathrm{H}_{2} \mathrm{O}, 0.036 \mathrm{~g} ; \mathrm{Na}_{2} \mathrm{CO}_{3}, 0.02 \mathrm{~g}$; $\mathrm{H}_{3} \mathrm{BO}_{4}, 2.86 \mathrm{~g} ; \mathrm{MnCl}_{2} .4 \mathrm{H}_{2} \mathrm{O}, 1.81 \mathrm{~g} ; \mathrm{ZnSO}_{4}, 0.222 \mathrm{~g} ; \mathrm{Na}_{2} \mathrm{MoO}_{4}, 0.39 \mathrm{~g}$; $\mathrm{CuSO}_{4} .5 \mathrm{H}_{2} \mathrm{O}, 0.079 \mathrm{~g}$; $\mathrm{Co}\left(\mathrm{NO}_{3}\right)_{2} .6 \mathrm{H}_{2} \mathrm{O}, 49.4 \mathrm{~g}$; Citric acid, $0.006 \mathrm{~g}$; ferric citrate, $0.006 \mathrm{~g}$; ampicillin, $50 \mu \mathrm{g} / \mathrm{mL}$; distilled water, $1000 \mathrm{~mL}$; agar, $20 \mathrm{~g}$; trace element solution A5, $1 \mathrm{~mL}$ ). All chemical reagents were analytical grade. All solutions were prepared by using deionized water.

\section{Microalgae cultivation}

Chlorella sp. was cultured in the BG-11 medium. The culture broth and the container were sterilized in an autoclave $\left(1.2 \mathrm{~kg} / \mathrm{cm}^{2}\right)$. Under sterile conditions, the algae seeds were evenly inoculated on the medium $(300 \mathrm{~mL})$, transferred to a conical flask $(500 \mathrm{~mL})$ and placed at $25( \pm 1){ }^{\circ} \mathrm{C}$ with a sterile breathable film sealing with the bottle mouth; then the whole bottle was illuminated under a LED growth lamp with a red to blue ratio of 5:1 for $24 \mathrm{~h}$, shaken three times a day at regular time.

\section{Shell calcining}

The cleaned shells were immersed in $1 \% \mathrm{HCl}$ for $24 \mathrm{~h}$ and calcined at $600{ }^{\circ} \mathrm{C}$, $700{ }^{\circ} \mathrm{C}$ and $800{ }^{\circ} \mathrm{C}$ for $2 \mathrm{~h}$ by using vacuum tube furnace (SKGL-1200-II, SIOMM, Shanghai) and muffle furnace (SX2-5-12, TAISITE, Tianjin), and sieved to $<100 \mu \mathrm{m}$ (average particle size: $75 \mu \mathrm{m}$ ) mesh particle size by micro-nano-pulverizer (MKCA62J, Masuko, Japan; Table 1).

Table 1. Experimental design

\begin{tabular}{c|c|c|c}
\hline Temperature & Muffle furnace & Vacuum tube furnace & Modified by $\mathbf{K}_{\mathbf{2}} \mathbf{C O}_{\mathbf{3}}$ \\
\hline $600{ }^{\circ} \mathrm{C}$ & $\mathrm{MM} 600^{\circ} \mathrm{C}$ & $\mathrm{MT} 600^{\circ} \mathrm{C}$ & MMM600 ${ }^{\circ} \mathrm{C}$ \\
$700^{\circ} \mathrm{C}$ & $\mathrm{MM} 700^{\circ} \mathrm{C}$ & $\mathrm{MT} 700^{\circ} \mathrm{C}$ & MTM700 ${ }^{\circ} \mathrm{C}$ \\
$800^{\circ} \mathrm{C}$ & $\mathrm{MM} 800^{\circ} \mathrm{C}$ & $\mathrm{MT} 800^{\circ} \mathrm{C}$ & MTM800 ${ }^{\circ} \mathrm{C}$ \\
\hline
\end{tabular}

\section{Activation of shell powder}

$0.5 \mathrm{~g}$ shell powder and $30 \mathrm{~mL}, 1 \% \mathrm{~K}_{2} \mathrm{CO}_{3}$ were dissolved to $50 \mathrm{~mL}$ tube, sonicated for $30 \mathrm{~min}$ by using an ultrasonic cleaning machine (G-040S, Geneng Cleaning Equipment Co., Ltd., Shenzhen, China, $600 \mathrm{w}$ ) and the sample was dissolved. The mixture was placed into a Teflon reactor at $160{ }^{\circ} \mathrm{C}$ for $24 \mathrm{~h}$. After filtering, precipitation was washed to neutrality and dried at $60^{\circ} \mathrm{C}$ for $8 \mathrm{~h}$.

\section{Modification by chitosan}

Chitosan, a linear polymer with high specific surface area, has the dual functions of electric neutral flocculation and adsorption flocculation, non-toxic and harmless, 
which is not only can provide nutrients for the growth of microalgae, but also conducive to the immobilization of microalgae.

$100 \mathrm{mg}$ chitosan and $10 \mathrm{~mL} \mathrm{HCl} \mathrm{(1 \% )} \mathrm{were} \mathrm{dissolved} \mathrm{in} 100 \mathrm{~mL}$ deionized water. The chitosan mixed with activated shell powder with a mass ratio of $1: 2$, stirring for 1 $\mathrm{h}$ and vacuum drying at $80{ }^{\circ} \mathrm{C}$ for $24 \mathrm{~h}$. The sample was marked as CS-M (Fig. 1).

\section{Preparation of immobilized microalgae}

$100 \mathrm{~mL}$ Chlorella sp., growing in logarithmic phase, $20 \mathrm{~mL}, 2 \%$ tea extract solution, $0.5 \mathrm{~g} \mathrm{CS}-\mathrm{M}$, stirring for $30 \mathrm{~min}$, standing in layers, removing as much supernatant as possible, adding $0.2 \mathrm{~g}$ Sodium alginate, $2 \mathrm{~mL}, 3 \%$ glycerol, stirring for $30 \mathrm{~min}$, standing for $2 \mathrm{~h}$, centrifugal separation, storage of the precipitate in sterile, sealed, dark conditions, storage temperature were $25{ }^{\circ} \mathrm{C}, 4{ }^{\circ} \mathrm{C},-24{ }^{\circ} \mathrm{C}$, respectively. $0.1 \mathrm{~g} \mathrm{CS}-\mathrm{M}$ and $1 \mathrm{~mL}$ steamed water, diluted 20 times, injected on slides, covered with coverslips. Optical microscopy (OM) was used to observe the combined situation of microalgae and shell powder under the ratio of $10 \times 10$ (ECLIPSE Ti, Nikon, Japan).

\section{Determination of chlorophyll-a (chl.a) content in immobilized microalgae}

$5 \mathrm{~mL}$ algae were centrifuged at $5500 \mathrm{r} / \mathrm{min}$ for $15 \mathrm{~min}$, collecting the precipitate, adding $5 \mathrm{~mL}, 80 \%$ acetone solution, extracting the chlorophyll-a in darkness at $4{ }^{\circ} \mathrm{C}$ for $24 \mathrm{~h}$ until the chl.a and acetone were fully mixed, centrifuge at $6000 \mathrm{r} / \mathrm{min}$ for 15 min. Finally, measuring the absorbance (OD) of supernatant by using UV-vis (UV2600, SHIMADZU, Japan) at $663 \mathrm{~nm}$ and $645 \mathrm{~nm}$ wavelength respectively, with the reference solution of $80 \%$ acetone. All tests are repeated three times.

Reference calculation formula of chl.a concentration (Gao and Sun, 2000) is as follows:

$$
\text { Concentration of chl. a }(\mathrm{mg} / \mathrm{L})=12.71 \times O D_{663}-2.59 \times O D_{645}
$$

$\mathrm{OD}_{645}, \mathrm{OD}_{663}$ : OD of the extract at $645 \mathrm{~nm}$ and $663 \mathrm{~nm}$ wavelengths, respectively.

\section{Test methods of microalgae cell density}

Take algae fluid, which cultivated in the BG-11 medium for $24 \mathrm{~h}, 48 \mathrm{~h}, 72 \mathrm{~h}, 96 \mathrm{~h}$, $120 \mathrm{~h}$, and $162 \mathrm{~h}$. The absorbance $\left(\mathrm{OD}_{680}\right)$ of the algae was measured at a wavelength of $680 \mathrm{~nm}$. After fixing with Rochelle's solution, the microalgae was diluted and counted its number using a hemocytometer (Shanghai refinement Biochemical Instrument Co., Ltd., Shanghai, China). Repeat three times and take the average. Establish a standard curve of $\mathrm{OD}_{680}$ and the number of microalgae cells.

\section{Characterization}

The specific surface area and porosity tester (BET) was used to analyze the specific surface area, and pore size distribution of shell powder under $77 \mathrm{k}$ with $\mathrm{N}_{2}$ is the analysis gas (Quadrasorb SI, Quantachrome, USA). The surface morphology of the sample was observed by using JSM-7800F ultra-high resolution thermal field emission scanning electron microscope (JEOL, Japan). 


\section{Statistical analysis}

Statistical analysis was performed using Origin 8.5 (Origin Corp., USA). All the experiments were performed independently at least three times.

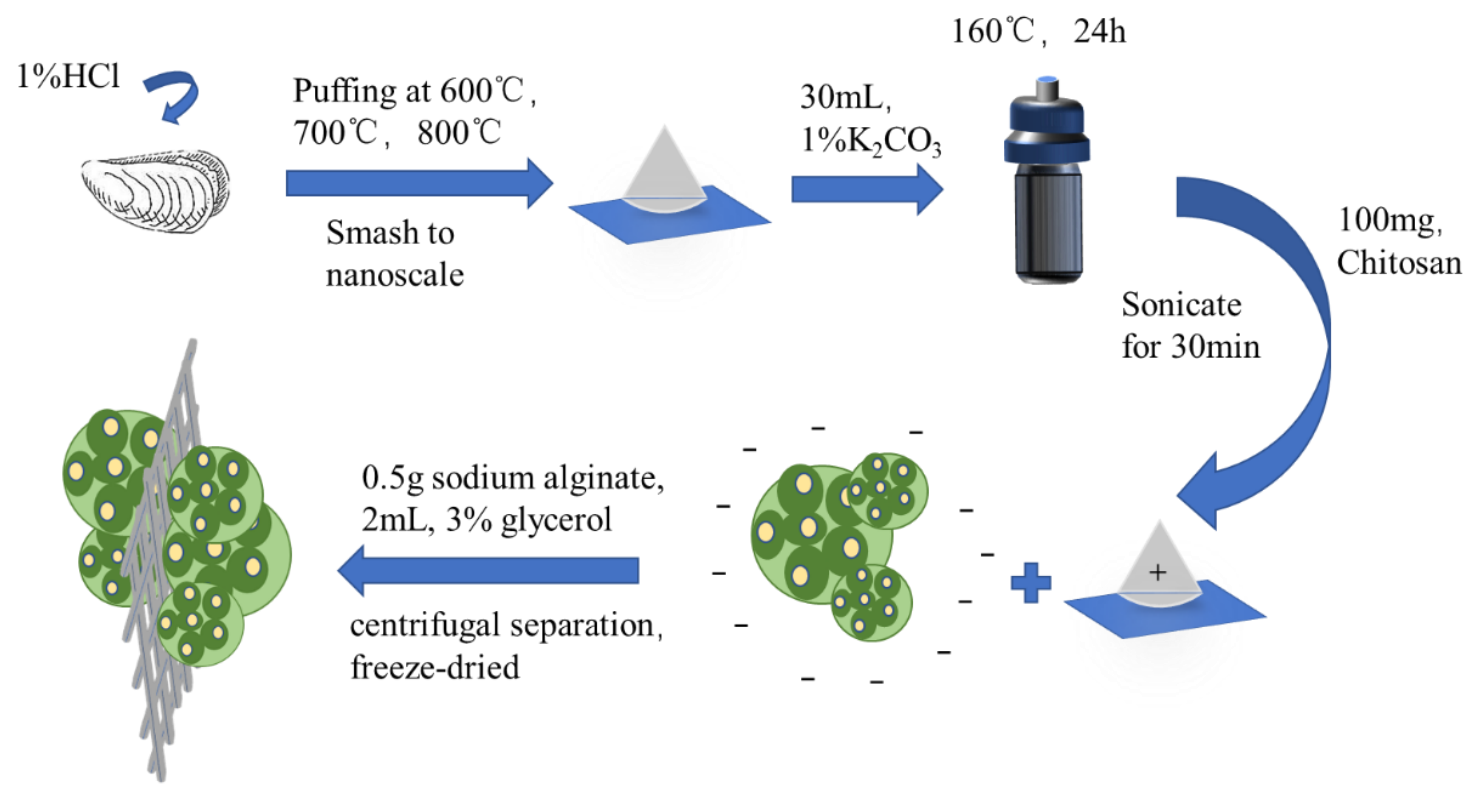

Figure 1. The schematic illustration of Chlorella sp. immobilized by nano mussel-shell powder and chitosan

\section{Results and discussion}

\section{BET characterization}

The curves of adsorption isotherms and pore diameter distribution of MM (mussel powder calcined by muffle furnace) and MT (mussel calcined by tube furnace) under $600{ }^{\circ} \mathrm{C}$ (a), $700{ }^{\circ} \mathrm{C} \mathrm{(b)} \mathrm{and800}{ }^{\circ} \mathrm{C}$ (c) are as shown in Figure 2. The isothermal adsorption curves of MM and MT at $600{ }^{\circ} \mathrm{C}$ and $700{ }^{\circ} \mathrm{C}$ are similar, and all type III (Sing, 1985). The lateral interaction between the adsorbed molecules is greater than the interaction between the adsorbent surface and the adsorbate. Adsorption takes place in multiple layers, and the amount of adsorption increases with enhancement of pressure. While the specific surface area of MM is generally superior to MT under $600{ }^{\circ} \mathrm{C}$, $1.308 \mathrm{~m}^{2} / \mathrm{g}$ vs $0.435 \mathrm{~m}^{2} / \mathrm{g}$ the average pore diameter of MT is about $5 \mathrm{~nm}$, while that of $\mathrm{MM}$ is about $2 \mathrm{~nm}$. The average pore diameters of MM and MT at $800{ }^{\circ} \mathrm{C}$ are not significantly different. The reason may be that the organic matter in shell powder has been completely decomposed since $700{ }^{\circ} \mathrm{C}$. Adsorption isotherms of $\mathrm{MM}$ at $800{ }^{\circ} \mathrm{C}$ has a hysteresis loop, which belongs to type $\mathrm{H}_{1}$, indicating that the pore distribution of the material is relatively narrow, the particle is spherical and its size is uniform. In general, the organic matter of shell powder will completely break down at $700{ }^{\circ} \mathrm{C}$. According to the average pore size of each material, it can be proved that the shell powder will form a well-distributed, less porous mesoporous material after high-temperature calcination. The puffing effect of the tube furnace is slightly better than that of the muffle furnace (Tables 2 and 3). 


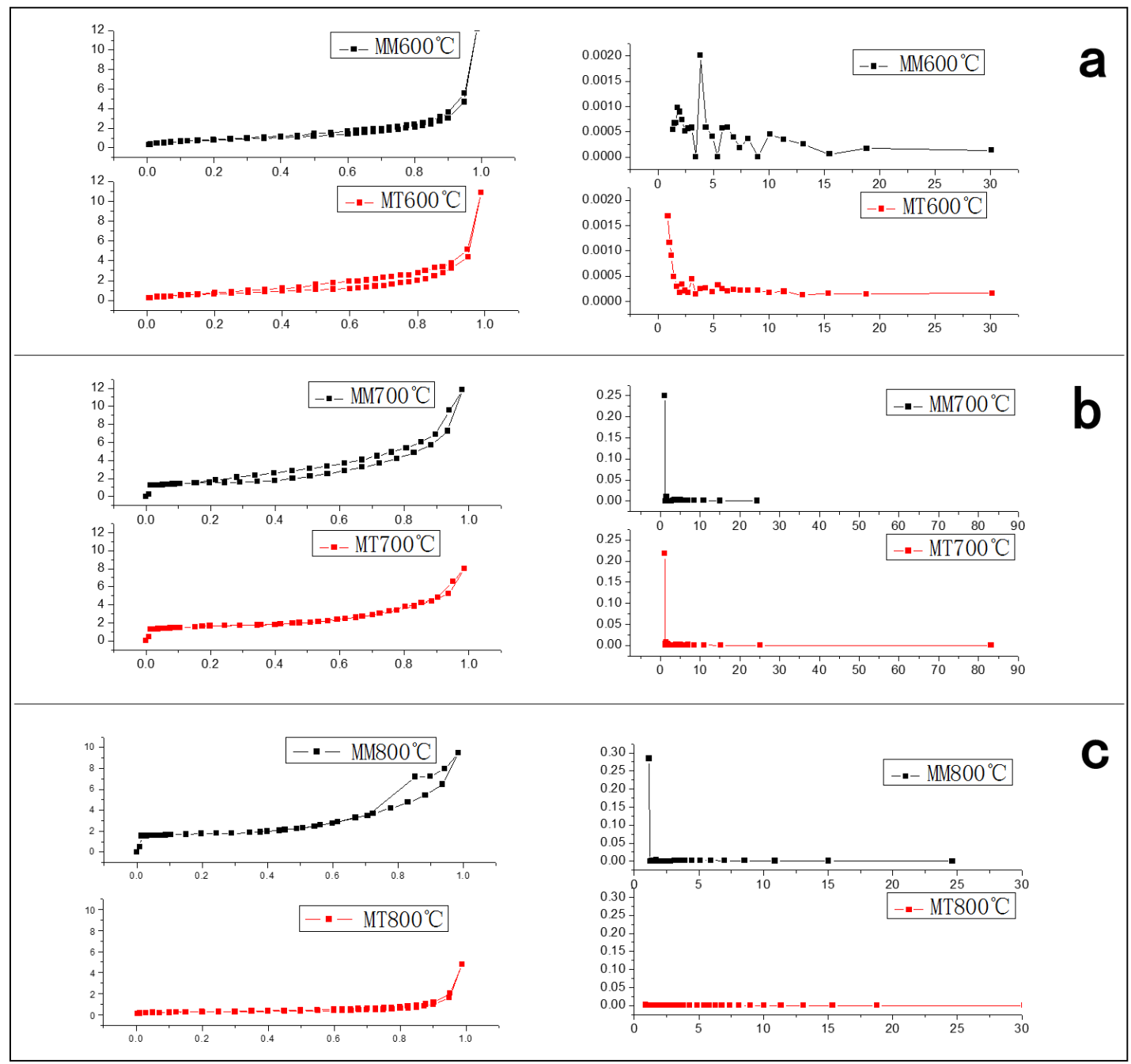

Figure 2. Adsorption isotherms and pore diameter distribution curves of MM and MT under different expansion temperatures $\left(600{ }^{\circ} \mathrm{C}, a ; 700{ }^{\circ} \mathrm{C}, \mathrm{b} ; 800^{\circ} \mathrm{C}, \mathrm{c}\right)$

Table 2. The specific surface area and average pore size of MM

\begin{tabular}{c|c|c|c}
\hline Temperature $\left({ }^{\circ} \mathbf{C}\right)$ & $\mathbf{6 0 0}$ & $\mathbf{7 0 0}$ & $\mathbf{8 0 0}$ \\
\hline Specific surface area $\left(\mathrm{m}^{2} / \mathrm{g}\right)$ & 1.308 & 5.538 & 12.45 \\
Average pore size $(\mathrm{nm})$ & 7.627 & 11.1078 & 4.9343 \\
\hline
\end{tabular}

Table 3. The specific surface area and average pore size of MT

\begin{tabular}{c|c|c|c}
\hline Temperature $\left({ }^{\circ} \mathbf{C}\right)$ & $\mathbf{6 0 0}$ & $\mathbf{7 0 0}$ & $\mathbf{8 0 0}$ \\
\hline Specific surface area $\left(\mathrm{m}^{2} / \mathrm{g}\right)$ & 0.435 & 1.2 & 0.965 \\
Average pore size $(\mathrm{nm})$ & 3.406 & 4.107 & 3.177 \\
\hline
\end{tabular}

The curves of adsorption isotherms and pore diameter distribution of MMM (MM modified by $\mathrm{K}_{2} \mathrm{CO}_{3}$ ) and MTM (MT modified by $\mathrm{K}_{2} \mathrm{CO}_{3}$ ) are as shown in Figure 3, 
whose calcined condition is $600{ }^{\circ} \mathrm{C}, 700{ }^{\circ} \mathrm{C}, 800{ }^{\circ} \mathrm{C}$. All the adsorption isotherms of MTM are type IV (Sing, 1985), similar to type III at first, but at higher pressures, the adsorption increase rapidly with the hole is condensed in capillary. However, the hysteresis loops appeared on the adsorption isotherms of MMM, regardless of temperature, which belongs to type $\mathrm{H}_{1}$. Comparing the surface area and average pore size of shell powder before and after modifying with $\mathrm{K}_{2} \mathrm{CO}_{3}$, we found that the average pore diameter of the shell powder, which calcined in the tube furnace, is greatly improved. The average pore size of shell powder increased from $3.406 \mathrm{~nm}$ to $15.176 \mathrm{~nm}$ at $600{ }^{\circ} \mathrm{C}, 4.107 \mathrm{~nm}$ to $16.557 \mathrm{~nm}$ at $700{ }^{\circ} \mathrm{C}$, and $3.177 \mathrm{~nm}$ to $7.804 \mathrm{~nm}$ at $800{ }^{\circ} \mathrm{C}$. But with the decrease of pore numbers, the specific surface area has reduced. The calcined shell powder in the muffle furnace does not have much difference before and after modification. We chose MTM $\left(700^{\circ} \mathrm{C}\right)$ as the best sample (Tables 4 and 5).

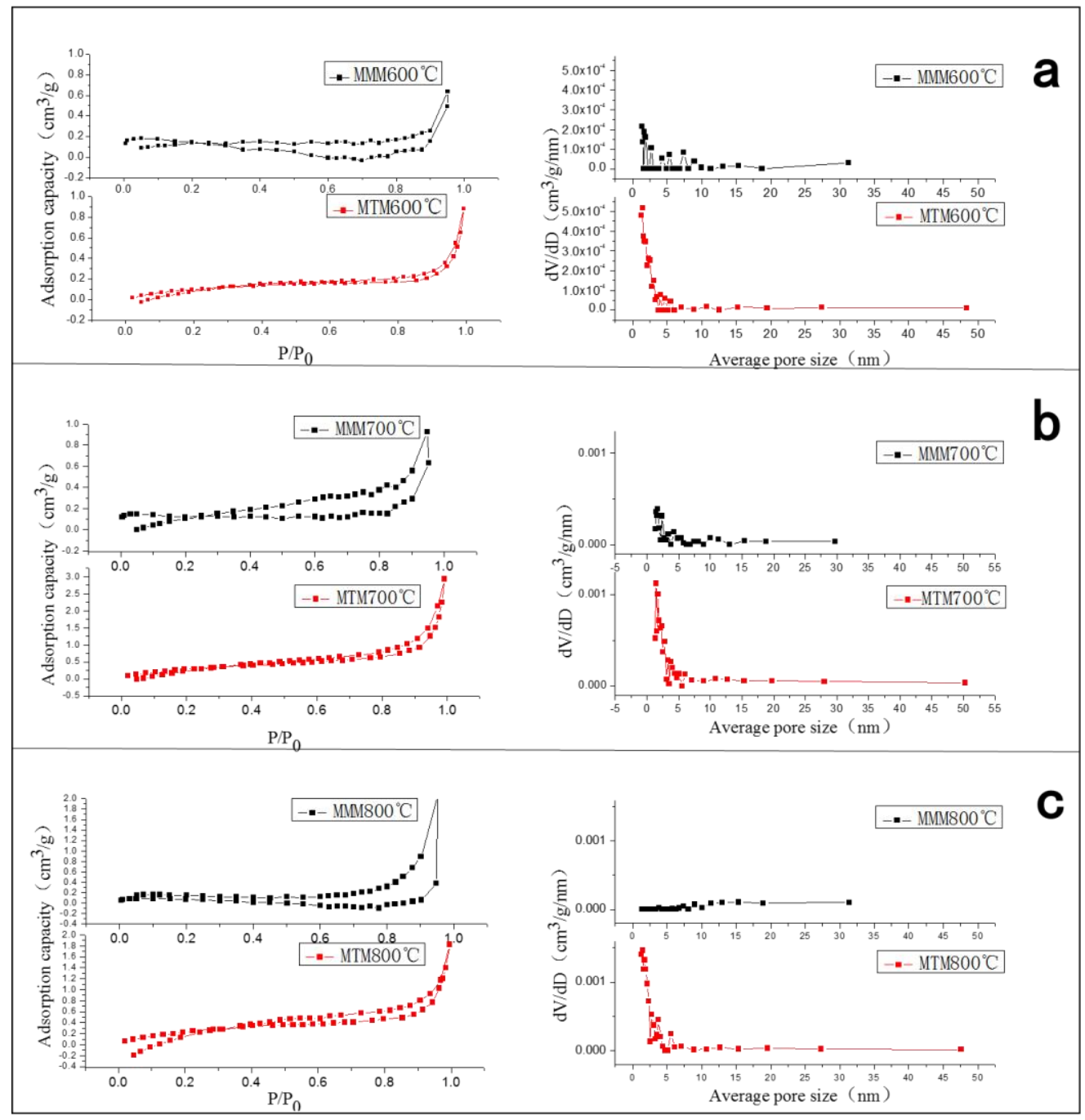

Figure 3. Adsorption isotherms and pore diameter distribution curves of MMM (MM modified by $\left.\mathrm{K}_{2} \mathrm{CO}_{3}\right)$ and MTM (MT modified by $\left.\mathrm{K}_{2} \mathrm{CO}_{3}\right)$ under different expansion temperatures $\left(600^{\circ} \mathrm{C}\right.$, $\left.a ; 700{ }^{\circ} \mathrm{C}, b ; 800^{\circ} \mathrm{C}, c\right)$

There are few reports on the use of biomass materials as carriers to immobilize microalgae. Shell powder, a excellent porous material, immobilizes microalgae by 
means of charge attraction and physical adsorption, has strong immobilization power and can provide certain nutrients to microalgae and prolong its life.

Table 4. The specific surface area and average pore size of MMM

\begin{tabular}{c|c|c|c}
\hline Temperature $\left({ }^{\circ} \mathbf{C}\right)$ & $\mathbf{6 0 0}$ & $\mathbf{7 0 0}$ & $\mathbf{8 0 0}$ \\
\hline Specific surface area $\left(\mathrm{m}^{2} / \mathrm{g}\right)$ & 2.894 & 5.4272 & 0.888 \\
Average pore size $(\mathrm{nm})$ & 7.086 & 12.600 & 9.019 \\
\hline
\end{tabular}

Table 5. The specific surface area and average pore size of MTM

\begin{tabular}{c|c|c|c}
\hline Temperature $\left({ }^{\circ} \mathbf{C}\right)$ & $\mathbf{6 0 0}$ & $\mathbf{7 0 0}$ & $\mathbf{8 0 0}$ \\
\hline Specific surface area $\left(\mathrm{m}^{2} / \mathrm{g}\right)$ & 0.336 & 0.364 & 0.123 \\
Average pore size $(\mathrm{nm})$ & 15.176 & 16.557 & 7.804 \\
\hline
\end{tabular}

\section{SEM characterization}

Two SEM photographs of $\mathrm{M}$ (Mussel calcined at $700{ }^{\circ} \mathrm{C}$ in a vacuum environment), MTM as shown in Figure 4, the texture of $\mathrm{M}$ is loose, and there are several pores on the surface, with the pore diameter is about $0.5 \mu \mathrm{m}$, which determines the excellent adsorption performance of shell powder. The size of pores in MTM is increased, compared with $\mathrm{M}$, which is $1 \mu \mathrm{m}$, because $1 \%$ potassium carbonate and water vapor have the good pore-forming ability, enhancing adsorption and sustained release capabilities of shell powder.
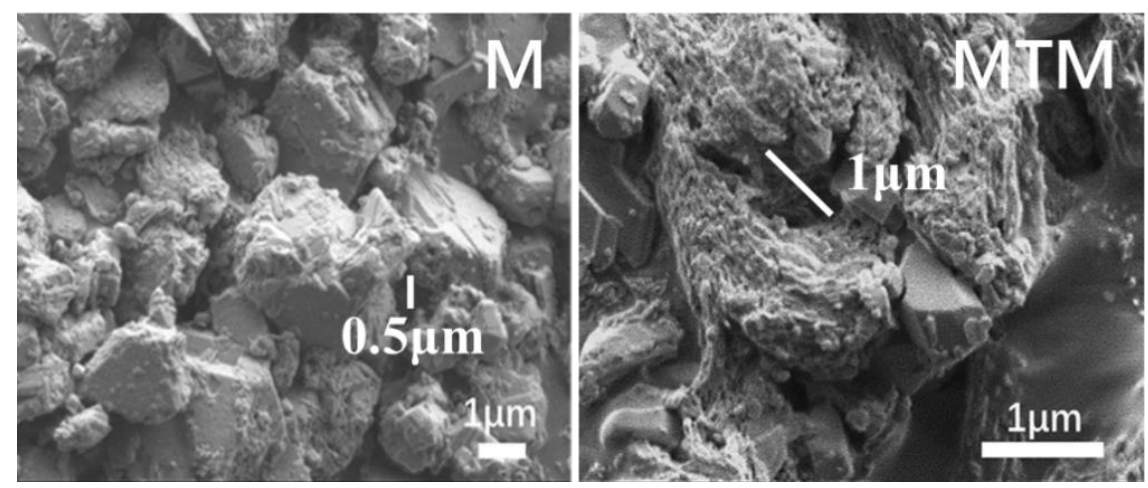

Figure 4. SEM images of $M$ and MTM

\section{OM characterization}

Photomicrographs of immobilized microalgae under a bio-optical microscope are shown in Figure 5. It can be seen that the diameter of shell powder is about $200 \mu \mathrm{m}$, and the chlorella sp. cells are about $10 \mu \mathrm{m}$ with a partial shell powder stacked. A large number of Chlorella sp. cells accumulate around the shell powder, indicating that modification of the shell by CS increased the "fixed" effect of the shell on the microalgae. It is beneficial to the dispersion of microalgae during the use of the immobilized microalgae. Sodium alginate also has a certain reinforcement and moisturizing effect. 


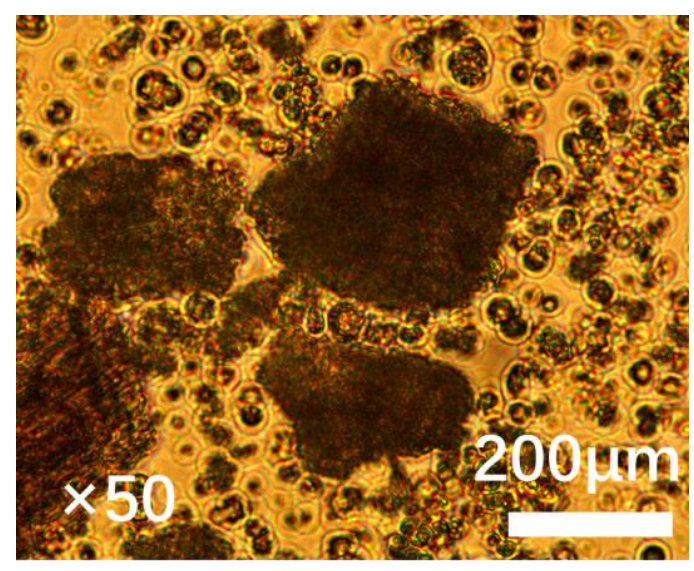

Figure 5. OM images of immobilized microalgae

\section{The growth of immobilized microalgae}

Growth curve of microalgae was determined in Figure 7a, during the preservation process, the chl.a content of all samples in the first 20 days changed slowly, however, after 20th day, decreased linearly. Loss rate of chl.a in immobilized microalgae after 60 days are respectively $59.04 \%, 50.22 \%, 42.77 \%$, with the content of chl.a are respectively $3.41778 \mathrm{mg} / \mathrm{L}, 4.72185 \mathrm{mg} / \mathrm{L}, 5.31715 \mathrm{mg} / \mathrm{L}$, which preserved in $25{ }^{\circ} \mathrm{C}$, $4{ }^{\circ} \mathrm{C}$ and $-24{ }^{\circ} \mathrm{C}$. The changes of chl. a content in immobilized microalgae at $4{ }^{\circ} \mathrm{C}$ and $24{ }^{\circ} \mathrm{C}$ are similar. However, it can be observed that there was a greatly decrease from 30th to 40th days at $25{ }^{\circ} \mathrm{C}$, from $6.88823 \mathrm{mg} / \mathrm{L}$ to $4.26672 \mathrm{mg} / \mathrm{L}$, which is the best growth temperature of microalgae, with a highest activity, but it can only perform respiration and cannot synthesize chl.a due to the dark environment. The nutrients provided by shell powder are limited. Over time, microalgae lacks nutrient intake, resulting in the death of a large number of microalgae and the loss rate of chl.a increased rapidly. The loss rate of chl.a was the lowest after 60 days, which kept at $24{ }^{\circ} \mathrm{C}, 42.77 \%$, probably because of the low activity of chlorella sp. at low temperature. In general, microalgae can survive 60 days in immobilized microalgae, which is rarely founded in recent research (Fig. 6 and Table 6).

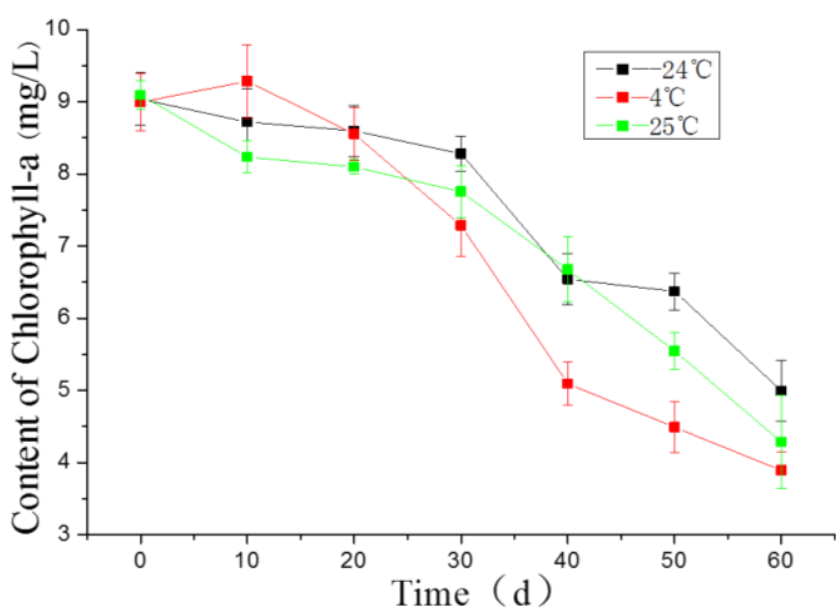

Figure 6. The curve of microalgae growth within 60 days under different storage conditions ($24^{\circ} \mathrm{C}, 4^{\circ} \mathrm{C}, 25^{\circ} \mathrm{C}$ ) 
Table 6. The loss rate of chl.a (\%) during 60 days in immobilized microalgae

\begin{tabular}{c|c|c|c}
\hline Storage conditions $\left({ }^{\circ} \mathbf{C}\right)$ & $\mathbf{2 5}$ & $\mathbf{4}$ & $\mathbf{- 2 4}$ \\
\hline Loss rate of chlorophyll-a $(\%)$ & 59.04 & 50.22 & 42.77 \\
\hline
\end{tabular}

\section{Regrowth of immobilized microalgae}

Regrowth curve of microalgae was determined in Figure $7 b$, the reactivation rate of microalgae in the immobilized microalgae at $4{ }^{\circ} \mathrm{C}$ is the fastest and the highest, with the cells number is up to $3.41769 \times 10^{6} \mathrm{cell} / \mathrm{mL}$ and the recovery rate is $26 \%$ (Table 7). The curves of Chlorella sp. cells number in immobilized microalgae are similar at $4{ }^{\circ} \mathrm{C}$ and $24{ }^{\circ} \mathrm{C}$, which have a rapid recovery period of microalgae from the 15 th day to19th day, and reaching the stable at the 9th day. However, the overall growth rate is slow at $25^{\circ} \mathrm{C}$. The reason may be the ultimate mortality of Chlorella $s p$. is high in the preservation process of immobilized microalgae, at $25{ }^{\circ} \mathrm{C}$. Generally, the resuscitation curve of microalgae in immobilized microalgae was consistent with the Logistic growth curve.
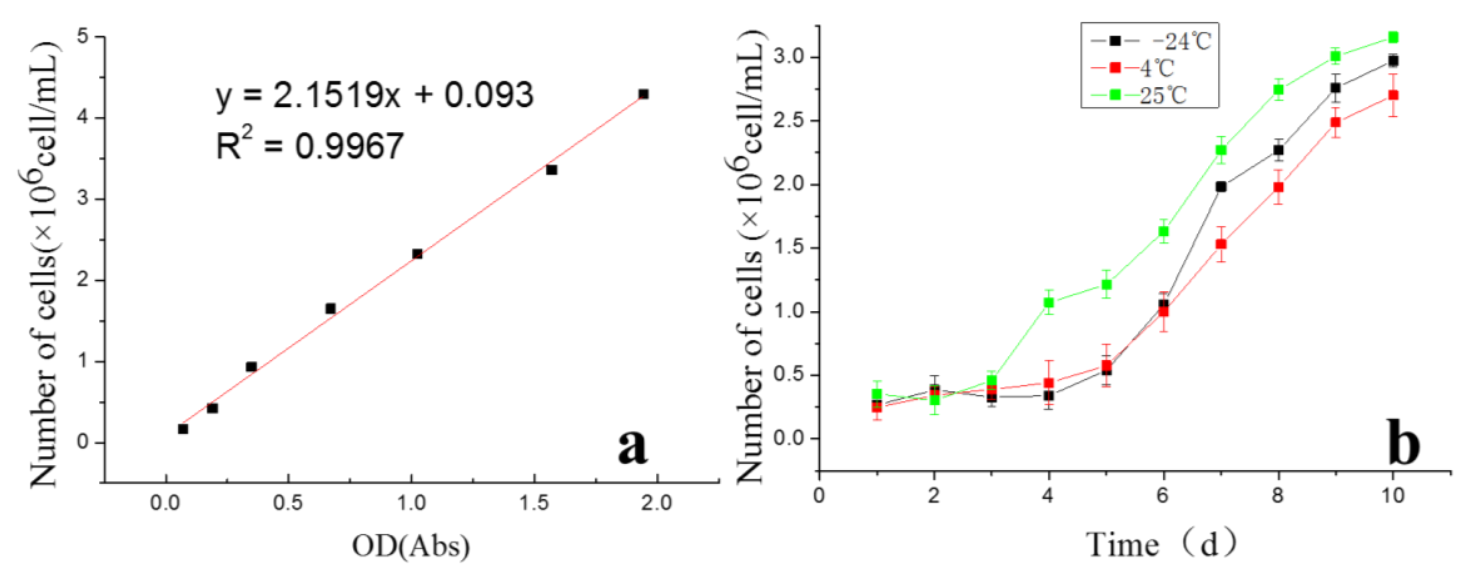

Figure 7. a. The stand curve of microalgae cells numbers. $\boldsymbol{b}$. The regrowth curve of microalgae within 10 days under different storage conditions $\left(-24{ }^{\circ} \mathrm{C}, 4^{\circ} \mathrm{C}, 25^{\circ} \mathrm{C}\right)$

Table 7. Recovery growth rate of microalgae (\%) during 60 days

\begin{tabular}{c|c|c|c}
\hline Storage conditions $\left({ }^{\circ} \mathbf{C}\right)$ & $\mathbf{2 5}$ & $\mathbf{4}$ & $\mathbf{- 2 4}$ \\
\hline Microalgae specific growth rate (\%) & 23 & 26 & 26 \\
\hline
\end{tabular}

\section{Conclusion}

In summary, it was found that the shell powder calcined at $700{ }^{\circ} \mathrm{C}$ in a vacuum tube furnace and hydrothermal modification with $\mathrm{K}_{2} \mathrm{CO}_{3}$ has the optimum pore structure with an average pore size of $16.557 \mathrm{~nm}$. The OM picture of CSM clearly shows that the Chlorella $s p$. is fixed with chitosan-modified shell powder, whose surface is positive. This structure can extend the shelf life of Chlorella $s p$. to 60 days and the best sample of the resurrection rate is $26 \%$, the number of cells is $3.41769 \times 10^{6}$ cell $/ \mathrm{mL}$, reviving at $4{ }^{\circ} \mathrm{C}$. With the rapid development of industrialization, this material has bright prospects. This is a new technology for immobilizing microalgae that can be used in water 
purification, energy harvesting and other fields, not only has the great significance for environmental protection but also for abandoned resources reuse.

Acknowledgements. This study was supported by the Natural Science Foundation of Zhejiang Province of China (No. LQ16D060004), Key Research and Development Projects of Zhejiang Province of China (No. 2018C02043), Demonstration Project of Marine Economic Innovation and Development of Zhoushan City of China, and Demonstration Project of Marine Economic Innovation and Development of Yantai City of China (No. YHCX-SW-L-201705).

\section{REFERENCES}

[1] Abdel-Raouf, N., Al-Homaidan, A. A., Ibraheem, I. B. M. (2012): Microalgae and wastewater treatment. - Saudi Journal of Biological Sciences 19(3): 257-275.

[2] Bruun, O. (2013): China's environmental challenges, by Judith Shapiro. - China Journal 70: 215-217.

[3] Chevalier, P., Noüe, J. D. L. (1985): Wastewater nutrient removal with microalgae immobilized in carrageenan. - Enzyme \& Microbial Technology 7(12): 621-624.

[4] Currey, J. D. (1977): Mechanical properties of the mother of pearl in tension. Proceedings of the Royal Society of London 196(1125): 443-463.

[5] Currie, J. A., Harrison, N. R., Wang, L., Jones, M. I., Brooks, M. S. (2007): A preliminary study of processing seafood shells for eutrophication control Asia-Pacific. Journal of Chemical Engineering 2(5): 460-467.

[6] Edralin, E. J. M., Garcia, J. L., Rosa, F. M. D., Punzalan, E. R. (2017): Sonochemical synthesis, characterization and photocatalytic properties of hydroxyapatite nano-rods derived from mussel shells. - Materials Letters 196: 33-36.

[7] Gao, J. F., Sun, Q. (2000): Botanical Physiology Experiment (Chapter 2). - The World Book Publishing Company, Shanxi.

[8] Jiménez-Pérez, M. V., Sánchez-Castillo, P., Romera, O., Fernández-Moreno, D., PérezMartíNez, C. (2004): Growth and nutrient removal in free and immobilized planktonic green algae isolated from pig manure. - Enzyme \& Microbial Technology 34(5): 392398.

[9] Kandilian, R., Jesus, B., Legrand, J., Pilon, L., Pruvost, J. (2017): Radiation transfer in agar immobilized microalgae cell cultures. - Journal of Quantitative Spectroscopy \& Radiative Transfer 198: 81-92.

[10] Li, M., Yao, Z. T., Chen, T., Lou, Z. H., Xia, M. (2014): The antibacterial activity and mechanism of mussel shell waste-derived material. - Powder Technology 264(3): 577582.

[11] Martínez-García, C., González-Fonteboa, B., Martínez-Abella, F., Carro-López, D. (2016): Performance of mussel shell as aggregate in plain concrete. - Construction \& Building Materials 139: 570-583.

[12] Moreira, S. M., Moreira-Santos, M., Guilhermino, L., Rui, R. (2006): Immobilization of the marine microalga phaeodactylum tricornutum, in alginate for in situ experiments. Bead stability and suitability. - Enzyme \& Microbial Technology 38(1-2): 135-141.

[13] Moreno-Garrido, I. (2008): Microalgae immobilization. Current techniques and uses. Bioresource Technology 99(10): 3949.

[14] Myers, J. (1980): Primary productivity in the sea. - Bulletin of Marine Science - Miami 32(3): 1-16.

[15] Nurdin, S., Rosnan, N. A., Ghazali, N. S., Gimbun, J., Nour, A. H., Haron, S. F. (2015): Economical biodiesel fuel synthesis from castor oil using mussel shell-base catalyst (msbc). - Energy Procedia 79: 576-583. 
[16] Okumura, K., Gennes, P. G. D. (2001): Why is nacre strong? Elastic theory and fracture mechanics for biocomposites with stratified structures. - European Physical Journal E 4(1): 121-127.

[17] Oswald, W. J., Gotaas, H. B., Golueke, C. G., Kellen, W. R., Gloyna, E. F., Hermann, E. R. (1957): Algae in waste treatment [with discussion]. - Sewage and Industrial Wastes 29(4): 437-457.

[18] Paradelo, R., Conde-Cid, M., Cutillas-Barreiro, L., Arias-Estévez, M., Nóvoa-Muñoz, J. C., Álvarez-Rodríguez, E. et al. (2016): Phosphorus removal from wastewater using mussel shell investigation on retention mechanisms. - Ecological Engineering 97: 558566.

[19] Robinson, P. K., Mak, A. L., Trevan, M. D. (1986): Immobilized algae: a review. Process Biochemistry 21(4): 122-127.

[20] Seki, H., Suzuki, A. (2002): Adsorption of heavy metal ions to floc-type biosorbents. Journal of Colloid \& Interface Science 249(2): 295-300.

[21] Sing, K. S. W. (1985): Reporting physisorption data for gas/solid systems with special reference to the determination of surface area and porosity (Recommendations 1984). Pure and Applied Chemistry 57(4): 603-619.

[22] Smidsrød, O., Skja K-Br1K, G. (1990): Alginate as immobilization matrix for cells. Trends in Biotechnology 8(3): 71-78.

[23] Solé, A., Matamoros, V. (2016): Removal of endocrine disrupting compounds from wastewater by microalgae co-immobilized in alginate beads. - Chemosphere 164: 516523.

[24] Spångberg, J., Jönsson, H., Tidåker, P. (2013): Bringing nutrients from sea to land mussels as fertiliser from a life cycle perspective. - Journal of Cleaner Production 51(51): 234-244.

[25] Timofeeva, L., Kleshcheva, N. (2011): Antimicrobial polymers: mechanism of action, factors of activity, and applications. - Applied Microbiology \& Biotechnology 89(3): 475-492.

[26] Wang, D., Zhao, T., Yan, L., Mi, Z., Qiang, G., Zhang, Y. (2016): Synthesis, characterization and evaluation of dewatering properties of chitosan-grafting dmdaac flocculants. - International Journal of Biological Macromolecules 92: 761-768.

[27] Wang, J., Qian, W., He, Y., Xiong, Y., Song, P., Wang, R. M. (2017): Reutilization of discarded biomass for preparing functional polymer materials. - Waste Management 65: 11 . 